\title{
New challenges in changing times: the digital educational support for financial literacy education
}

\author{
Elena Akimova ${ }^{1 *}$, Natalya Korshunova ${ }^{2}$, Alexander Fedorov ${ }^{3}$, Olga Shatayeva ${ }^{3}$, and Olga \\ Shipkova ${ }^{4}$ \\ ${ }^{1}$ Moscow Region State University, Institute of Economics, Management and Law, Department of \\ Economic Theory, Mytishi, Russia \\ ${ }^{2}$ D. Mendeleev University of Chemical Technology of Russia, Faculty of Humanities, Department of \\ Sociology, Moscow, Russia \\ ${ }^{3}$ Moscow State Pedagogical University, Institute of Social Studies and Humanities, Department of \\ Economic Theory and Management, Moscow, Russia \\ ${ }^{4}$ National University of Science and Technology MISIS, Institute of Economics and Industrial \\ Enterprise Management named after V. A. Roments, Department of Economics, Moscow, Russia
}

\begin{abstract}
Globalization, internationalization and international regionalization are the leading trends and the key factors that determine radical shifts and systemic changes in the Russian Federation as well in the other countries to meet quite new perspectives, opportunities and resources for its further cultural, social and economic development in a way of innovations and knowledge society creation. The strategies of social and economic development of the Russian Federation are tightly connected with perspectives of global digitalization, and they have a great impact on the present-day education digital transformation. The article actualizes a problem of financial illiteracy educations and the ways of its improvement by means of digital educational support orientated to development financial competences among students. Quite new educational and pedagogical tools and technologies have recently been introduced in financial education (educational platforms, e-learning, online games, online courses, simulators, digital textbooks, etc.). Under their influence there is a rapid formation and development of new educational environment, virtual and digital. Financial literacy education is becoming more individualized under the influence of its digital transformation. The center of gravity in learning shifts from teaching (instruction) to student activity, therefore, teacher's professional position in teaching and learning changes. Teaching becomes more virtualized and digitalized under the influence of the virtual and digital educational environment. The functions of digital educational support in financial literacy education are characterized.
\end{abstract}

Keywords: financial literacy education; competences; educational technologies; digital educational support.

*Corresponding author: eakimova@mail.ru 


\section{Introduction}

The civilization is experiencing the influence of the greatest paradigm change in a rather inconsistent situation of social and economic instability, turbulence and uncertainty. The dynamics of deformation of traditional fundamental paradigms, concepts, social institutions and values, that has previously ensured the integrity of the socio-cultural space of human life has been increasing for the last decade [1,2]. Effective solving the problem of financial literacy of the present-day developing consumer society is particularly actual, and it represents one of the most significant challenges for education nowadays [3-6]. It has become a global problem. The analysis of the educational and pedagogical experience of educational organizations in the United States, Great Britain, Germany, France, Russia and in the other countries proves the fact that the digital educational support can be seen as an effective instrument for improving financial literacy education it due to its specific resources and opportunities (informational, educational, pedagogical, communicative and media) [7-10].

All of the above mentioned actualizes the problem of the digital educational support of financial literacy education.

\subsection{Problem statement}

In the scientific literature, there are many approaches to defining the category of "personal financial literacy" $[11,12]$. We share the point of view of those researchers who define it as "the ability to read, analyze, manage, and communicate about the personal financial conditions that affect material well-being. It includes the ability to discern financial choices, discuss money and financial issues without (or despite) discomfort, plan for the future, and respond competently to life events that affect everyday financial decisions, including events in the general economy" [13]. This definition is quite close to that given by the OECD [14-16].

\subsection{Research questions and purpose of the study}

In this study our main question was formulated in the following way, "What do digital competences mean and what are the main the main digital educational support in the process of their development?"

\section{Materials and methods}

The study included: (a) an analysis of the present day state policy of the Russian Federation in development of digitalization of national economy as well as the state policy of the Russian Federation in Education and, particularly, in financial literacy education (legislation, national initiatives, strategies, action plans, target programs and national project, etc., connected with aspects mentioned above); (b) an analysis of the content of financial literacy education at universities; (c) approbation of the technology of digital educational support in financial literacy education of university students; (d) data collection, data analysis and interpretation; analytic framework and modelling.

\section{Results}

1. Due to the new paradigm of the civilization development, education is integrating with culture actively. That also concerns to a digital culture. In this aspect, education is to 
fulfil quite new functions, such as: (a) facilitation and stimulation of "inner forces" of an individuality (interests, values, meanings, orientations demands and motives of cognitive activity and social practices) in a situation of an educational alternative and an educational choice; (b) development and support of an individualized educational environment to assist an individuality to construct and to implement his own unique educational route; (c) joint creation of new ways of social and pedagogical interaction realized on the basis of the wider repertoire of educational and pedagogical discourses (individualization, differentiation and personalization). In the long run, the mission of the present-day education is focused on the development of skills and competencies of the 21 st century.

2. The Priority National Project "Education" (2019-2024) plays a special role in the process of digital transformation of education. It consists of several subprojects, but the subprojects "The Modern School", "The Digital Educational Environment" and "The Teacher for the Future" fulfil the functions of the main strategies of development of national system of education tightly connected with the systemic process of digital transformation of the Russian society and economics.

In the long run, the new strategies of education in the Russian Federation for the $21 \mathrm{st}$ century are tightly connected with the perspectives of: (a) virtual and digital schools and universities; (b) virtual and digital educational environment; (c) new ways of educational and pedagogical interaction that determine quite new technologies, methods and tools of teaching and learning on the bases of the individualized educational process with individual teaching and learning trajectories; (c) new actors of the educational process (including "digital" teachers and "digital" students). At the same time, at about 4 of 10 teachers in the USA and in Russia say their educational institutions are "behind the curve". $75 \%$ of teachers in the USA and some $92 \%$ of teacher in Russia believe that digital learning content will totally replace printed textbooks within the next 10 years (and this is one of the outcomes of effective implementation of the "Russian Digital School" project recently). $[17,18]$.

3. The Strategy of improvement of financial literacy of the citizens of Russian Federation was approved by the Government of Russian Federation on September, 25, 2017. According to the Strategy, financial literacy is meant as the result of the process of financial education, which is defined as a combination of awareness, knowledge, skills, and behavioral patterns required for decision-making successful financial decisions and ultimately to achieve financial well-being. Financial education is defined as a process, by which one financial services consumers (investors) improve their understanding financial products, concepts, and risks, and using information, they develop their skills and raise awareness about financial risks and opportunities, make an informed choice in relation to financial products and services, they know where to apply for help, as well as take other effective measures to improve your financial situation.

4. Since 2012 the Central Bank of Russian Federation in partnership with universities leads a system work to develop and implement educational models of financial literacy education. Methodological and resource centres for financial literacy education were founded in Moscow State University, Moscow High School of Economics and in Moscow Pedagogical State University in 2017-2019.

5. As it is stated in the G20/OECD INFE "Core Competences Framework on Financial Literacy for Adults", "the term 'core competencies' as one of the main goals of financial literacy education support and its result refers to the aspects of knowledge, behaviours and attitudes that form the basis of sound financial decisions; they are considered to be the main, or primary financial literacy competencies that could benefit an individual. It is anticipated that a combination of these core competencies, based on personal needs and the cultural and economic context, will enable an individual to maintain or improve financial well-being throughout life" [15, p. 6]. 
6.It is quite evident that financial competences refer to a range of different abilities. They are represented by various combinations of different ways of behavior, expertise, know-how, work habits and skills, character traits, dispositions and critical understandings. Researchers state the fact that digital skills and financial competencies are interconnected. They are broadly complementary. They need to be developed and refined over time according to individual and professional circumstances.

7. The vision of the digital educational support of financial literacy education consists of four basic elements tightly connected with each other: (a) educational community; (b) individualized and personal educational environments; (c) individualized coaching; (d) LMS and LCMS as automatic systems of management of learning and its content.

No wonder, that the same concerns the image of students and teachers in the digital educational environment-they are also becoming "digital". In the nearest future the digital educational support based on educational platforms will bring quite new educational opportunities: artificial intelligence and virtual reality, chatbots and gamification, cloud computing and social media will change the image of the traditional classroom educational environment and, as a whole, the infrastructure of education making it digital (the digital content, mass distribution and personalized learning) [19, p. 13].

\section{Conclusion}

The analysis of the problem of digital educational support in financial literacy education allows us to conclude that despite the fact that teachers are aware of the importance of teaching digital transformation in the future and their professional deficits at present, the vast majority of them are not yet ready to fully accept innovations. At the same time they are trying to find more adequate ways, methods and technologies to implement them in the educational process at the lessons of financial literacy. They are: digital educational materials (electronic textbooks and manuals for students, video, mass media, calculators), new social and teaching media, Internet meetings for brainstorming and co-working, eportfolio, video conferences, Internet financial practice, digital project activity, etc.

The results of the study were used in design and implementation of a new digital educational course on Financial Literacy for students in the Moscow Pedagogical State University, Moscow Region State University, National University of Science and Technology MISIS and in the Russian University of Chemical Technology named after D.I. Mendeleev. A joint digital educational resource on the basis of the Moodle educational platform was created and implemented into the educational process. Its usage in the digital support of financial literacy education was quite effective. Special recommendations and manuals for teachers were prepared to assist them to provide the technology of support more effective.

\section{References}

1. V. Stepin, Chelovek. Deiatelnost. Kultura [Person. Activity. Culture] (Saint-Petersburg University of Humanities and Social Sciences, Saint-Petersburg, 2018)

2. V. Lektorskiy, Chelovek I Kultura [Person and Culture] (Saint-Petersburg University of Humanities and Social Sciences, Saint-Petersburg, 2018)

3. Agency of Strategic Initiatives, Skolkovo Innovation Center, Atlas of New Professions 2030 (2015). Accessed on: December 16, 2020. [Online]. Available: http://atlas100.ru/about/ 
4. C. Redecker, European Framework for Digital Competence of Educators:

DigCompEdu (Publication office of the European Union, Luxemburg, 2017).

http://dx.doi.org/10.2760/159770

5. C.H. Reschke, S. Kraus, Evolut Inst Econ Rev, 5(2), 259-278 (2009). https://doi.org/10.14441/eier.5.259

6. I.D. Froumin, M.S. Dobryakova, K.A. Barannikov, I.M. Remorenko, Key competences and new literacy: from slogans to school reality. Modern education analytics, 19, (Institute of Education of Higher School of Economics, Moscow, 2018)

7. D.J. Loveless, P.M. Sullivan, Deconstructing the education-industrial complex in the digital age (IGI Global, Hershey, PA, 2017)

8. D. Newman, Top 6 Digital Transformation Trends in Education (2017). Accessed on: December 16, 2020. [Online]. Available:

https://www.forbes.com/sites/danielnewman/2017/07/18/top-6-digital-transformationtrends-in-education/\#12cf69812a9a.

9. European Commission, 2nd Survey of Schools: ICT in Education (2019). Accessed on: December 16, 2020. [Online]. Available: https://ec.europa.eu/digital-singlemarket/en/news/2nd-survey-schools-ict-education

10. Broadband Commission for Sustainable Development, Working Group on Education, Digital skills for life and work (UNESCO, Paris, 2017). Accessed on: December 16, 2020. [Online]. Available: http://d-russia.ru/wp-content/uploads/2017/10/Digital-skillsfor-life-and-work_259013e.pdf

11. S. Greiff, S. Wüstenberg, B. Csapó, A. Demetriou, J. Hautamäki, A.C. Graesser, R. Martin, Educational Research Review, 12, 74-83 (2014). http://dx.doi.org/10.1016/j.edurev.2014.10.002

12. T. Barkatsas, A. Bertram (Eds.), Global learning in the 21 st century (Sense Publishers, Boston, MA, 2016)

13. L.A. Vitt, C. Anderson, J. Kent, D.M. Lyter, J.K. Siegenthaler, J. Ward, Personal Finance and the Rush to Competence: Financial Literacy education in the U.S. A National Field Study Commissioned and Supported by the Fannie Mae Foundation (Institute for Socio-Financial Studies, Middleburg, Virginia, 2000)

14. OECD, Financial Education in Europe (OECD Publishing, Paris, 2016a). http://dx.doi.org/10.1787/9789264254855-en

15. OECD, G20/OECD INFE Core Competencies framework on Financial Literacy or Adults (OECD Publishing, Paris, 2016b). Accessed on: December 16, 2020. [Online]. Available: http://www.oecd.org/finance/Core-Competencies-Framework-Adults.pdf

16. OECD, Global competency for an inclusive world (OECD Publishing, Paris, 2016c). Accessed on: December 16, 2020. [Online]. Available: https://www.oecd.org/education/Global-competency-for-aninclusive-world.pdf

17. Deloitte, 2016 Digital Education Survey "After the bell rings: expanding the classroom". Emerging trends in digital education technology devices and materials (Deloitte Development LLC, New York, 2016). Accessed on: December 16, 2020. [Online]. Available:

https://www2.deloitte.com/content/dam/Deloitte/us/Documents/technology-mediatelecommunications/us-tmt-digital-education-survey.pdf

18. M.S. Dobryakova, O.V. Yurchenko, E.G. Novikova, Developing 21 st century skills in russian schools:teachers' and parents' views, Modern education analytics, 21(4) (Institute of Education of Higher School of Economics, Moscow, 2018). Accessed on: 
December 16, 2020. [Online]. Available:

https://ioe.hse.ru/data/2018/11/21/1141648307/CAO_4(21)_электронный.pdf

19. CISCO, The next-generation digital learning environment and a framework for change for educational institution: CISCO White Paper, 13-14 (2018). Accessed on: December 16, 2020. [Online]. Available:

https://www.cisco.com/c/dam/en_us/solutions/industries/docs/education/digitallearning-environment.pdf 